\title{
Feminisation of male clams Scrobicularia plana from estuaries in Southwest UK and its induction by endocrine-disrupting chemicals
}

\author{
W. J. Langston*, G. R. Burt, B. S. Chesman \\ Marine Biological Association of the United Kingdom, The Laboratory, Citadel Hill, Plymouth PL1 2PB, UK
}

\begin{abstract}
The risk of endocrine disruption in the marine environment is unclear and is often overlooked in invertebrates. We show that disruption to the 'normal' gonadal development of male estuarine clams Scrobicularia plana is occurring extensively at sites in Southwest UK, with populations exhibiting varying degrees of intersex (ovotestis). This is one of the few studies to have examined the extent of the condition in mollusc populations. Intersex was present in more than two-thirds of the populations screened from the Avon, Southampton Water, Bristol Channel/Severn, Erme, Plym, Fal, Tamar and Lynher Estuaries; severity varied, with between 0 and $60 \%$ of males exhibiting the condition. Prevalence of intersex tended to peak as gonads reached maturity in July, and was highest in clams from the Bristol Channel and Severn Estuary, coinciding with an increase in oocyte size in both the female gonad and in the ovotestis of affected males. Experimental exposures to sediment spiked with mixtures of 17ß-oestradiol (E2), 17 $\alpha$-ethinyloestradiol (EE2), octylphenol (OP) and nonylphenol (NP) indicated that (xeno)estrogens could be a contributory factor in the induction of intersex and increased oocyte size. It is plausible, therefore, that the incidence of ovotestis may be linked to urban, industrial and agricultural influences, or a combination thereof, although the relative importance of these sources has yet to be determined. S. plana offers potential as a sentinel species for screening and investigation of endocrine disruption in the estuarine environment, helping to focus remediatory strategy where it would be most beneficial.
\end{abstract}

KEY WORDS: Endocrine disruption $\cdot$ Intersex $\cdot$ Ovotestis $\cdot$ Scrobicularia plana $\cdot$ Estuaries

\section{INTRODUCTION}

It is now well-established that various natural and man-made compounds in domestic and industrial effluents are capable of altering reproductive processes in wildlife. Endocrine disruption (ED) of male fish in UK rivers occurs extensively and is known to be caused by steroidal hormones discharged via sewage treatment works (notably the natural steroids 17 $\beta$ oestradiol [E2], oestrone [E1] and the synthetic hormone $17 \alpha$-ethinyloestradiol [EE2]) together with xenoestrogens - compounds that mimic or enhance the effects of endogenous oestrogens (Tyler et al. 1998). The list of candidate endocrine disrupting chemicals (EDCs), other than hormones, is extensive and in- cludes alkylphenols such as octyl- and nonylphenol (OP, NP), phthalates, chlorotriazines, dioxins, cadmium, mercury, lead, PAHs, PCBs, PCDDs, PCDFs, and various pesticides (Lintelmann et al. 2003). Laboratory studies are now helping to determine the potency of these various EDCs and the most likely threats to the aquatic environment (Tyler \& Routledge 1998, Jobling et al. 2003). A major uncertainty still to be resolved, however, is the nature and scale of ED in estuarine and marine ecosystems (Langston et al. 2005).

Manifestation of the effects of ED in freshwater fish includes the condition known as intersex (ovotestis: the simultaneous presence of both testicular and ovarian tissue in the male gonad) in varying degrees. Most 
intersex fish tend to contain small numbers of female germ cells, or oocytes, within a predominantly male gonad (testis), though in severe cases large areas of ovarian tissue may be separated clearly from testicular tissue. There may also be disruption, malformation and blockage of the male reproductive ducts and a female-like duct or ovarian cavity (Nolan et al. 2001, Jobling et al. 2002a). A small number of studies have recorded similar effects in estuarine fish, including flounder, and recently in dab from remote sites offshore, such as the Dogger Bank (Allen et al. 1999, Stentiford \& Feist 2005). Unfortunately, from a monitoring viewpoint, fish such as dab and flounder migrate extensively, especially between breeding and feeding grounds, and there may be uncertainty over the exposure site and regime during the critical gonad developmental period. The use of fish in marine monitoring programmes is therefore currently circumspect, to an extent, although they undoubtedly highlight important regional differences in ED.

A further significant knowledge gap relates to the possibility that much of the oestrogenicity in aquatic environments may reside in benthic sediments (Peck et al. 2004) and, if bioavailable, may affect benthic biota (and can be transferred eventually through the food chain). Given the current debate over the presence of ED in the marine environment, the question of whether anthropogenic forces can influence the sexuality and reproduction of aquatic invertebrates is particularly important, as invertebrates comprise $95 \%$ of all animal species and are central to ecosystem function (Defur et al. 1999).

Molluscs appear to be a suitable phylum for study in this respect as there is evidence that they have sensitive, steroidally influenced reproductive systems. Laboratory exposure experiments have demonstrated the potential for ED in some gastropods (Oehlmann et al. 2000, Jobling et al. 2003), and tributyltin (TBT)-induced effects are known to occur widely in the field (Bryan et al. 1986, Langston et al. 1990, Horiguchi et al. 2000). However, whilst there are a few examples indicating localised effects of ED in freshwater mussels (e.g. gonadal development and maturation in Dreissena polymorpha are affected by industry-derived pesticide exposure: Binelli et al. 2001, 2004), there are no reports of oestrogenic ED effects occurring widely in native marine bivalve populations.

Intuitively, estuaries are likely to be among the most affected marine sites because of their proximity to land-based sources of contamination; however, because of low biodiversity in estuaries, the choice of organisms for investigation is rather limited. Also the sexual identity of molluscs is variable: in bivalves this ranges from strict gonochorism (separate sexes) to functional hermaphroditism (Delgado et al. 2002).
There is also a suggestion that some bivalves may switch readily between reproductive states (Mackie 1984). The common estuarine bivalve Scrobicularia plana (Da Costa, 1778) has many attributes promoting its use in ED studies, not least being that it has previously been reported to be inherently gonochoristic (Hughes 1971, Ruiz 1993, Rodríguez-Rúa et al. 2003). $S$. plana is abundant in many estuaries, lagoons and bays along much of the NE Atlantic seaboard, from Norway to the Mediterranean and West Africa, and is common around the UK. Spawning takes place once a year in summer (usually July/August) in the northern part of this range (including the UK), and is presumably constrained by temperature. Further south, along the Spanish, Portuguese and North African coasts, there may be 2 or even 3 cohorts produced during a prolonged spawning period between spring and autumn (Essink et al. 1991, Sola 1997, Rodríguez-Rúa et al. 2003).

Throughout their range, these euryhaline clams are recognised to be key species of the estuarine intertidal and, to a lesser extent, shallow subtidal soft-substrate communities (Essink et al. 1991). Clam densities of several thousands $\mathrm{m}^{-2}$ are not unusual, especially following spatfall, and the species may be responsible for a large proportion of the energy flow and secondary production on intertidal flats (Casagranda \& Boudouresque 2005). Consequently, Scrobicularia plana is a major component in the diets of fish, crabs and wading birds, potentially transferring EDCs along food chains. There is also increasing commercial interest in larger individuals as a human food resource, particularly in southern Portugal and Spain. Its extensive distribution, ecological importance, and sedentary lifestyle therefore promote $S$. plana as a valuable indicator species, a feature which has been exploited extensively for monitoring bioaccumulation of contaminants (see for example Bryan \& Langston 1992). As a deposit-feeder, $S$. plana is particularly responsive to a number of sediment-associated contaminants, including known EDCs such as TBT (Langston et al. 1990, Langston \& Burt 1991, Ruiz 1993, Ruiz et al. $1994 \mathrm{a}, \mathrm{b})$ : if oestrogenic activity resides principally in sediment, as suggested, $S$. plana might be considered sensitive to ensuing effects and has ideal credentials as a sentinel species.

To test this hypothesis we examined, histologically, the reproductive condition of a number of populations of Scrobicularia plana in diverse estuaries of the Southwest UK and performed preliminary experiments to investigate effects of model EDCs on gonadal development. We present evidence of widespread feminisation of male clams in the region, which may be linked to urban, industrial and agricultural influences. 


\section{MATERIALS AND METHODS}

Field sampling and histological examination. A programme of regular sampling of Scrobicularia plana and sediment was started in 2004 in the Avon Estuary, south Devon, UK (Fig. 1), selected tentatively as a likely 'reference' site because of its low level of urbanisation and industry. The intention was to use these samples to establish 'normal patterns' of gametogenesis over seasonal and annual cycles, to test methodologies, and to act as stocks for experiments. Samples were collected at least monthly during the period of gonad maturation and spawning (May to September) and less regularly outside this period, when gonadal tissue was largely undifferentiated.

In addition to long-term observation of the Avon population, Scrobicularia plana was sampled during the period of peak gonad development (June to September) in a range of other estuaries in the Southwest UK (Fig. 1), in 2004 and 2005. These included the Erme, Plym, Tamar, Lynher and Fal Estuaries in Devon and Cornwall, the Bristol Channel and Severn Estuary (South Wales) and also the Test, Itchen and Hamble Estuaries in Southampton Water (Fig. 1: see Fig. 4 for individual site names). In an attempt obtain evidence of reproductive anomalies in the field and to scale any changes relative to 'baselines', the study locations encompassed a range of conditions: urbanised/industrialised sites close to sewage treatment discharges and landfill (upper Plym and upper Itchen, Woolston, Dalton's Point, Barry, Penarth, Rhymney), dockyards (Cracknore, Wilcove), metal-contaminated sediments (Fal), as well as more rural sites (Avon, Erme, Lynher, upper Tamar).

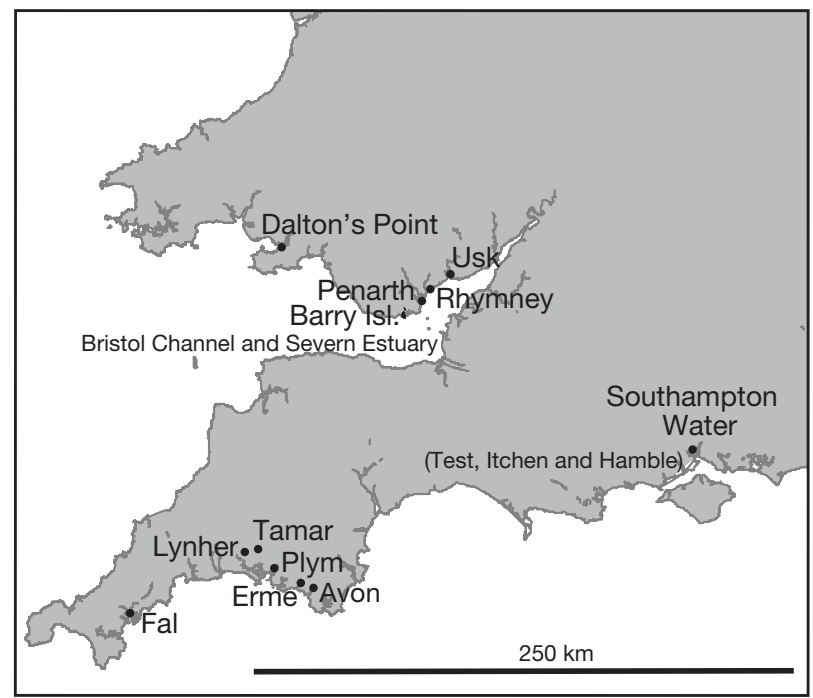

Fig. 1. Scrobicularia plana. Sampling sites in Southwest UK
Scrobicularia plana reaches sexual maturity 2 to $3 \mathrm{yr}$ after settlement, by which time shell lengths are $>20 \mathrm{~mm}$. At most sites, approximately 30 'adult' clams (mean shell length $34.1 \pm 6.5 \mathrm{~mm}$ ) were collected by digging from inter-tidal mudflats. A larger sample of clams (150) from the Avon Estuary was also examined on 1 occasion (7 July 2005) to assess whether information was lost by restricting the standard sample size to $\sim 30$. All field collections were mixed-sex samples since there is no external distinction between male and female clams. The $S$. plana were placed in sediment, in cool boxes, and transported to the laboratory, where they were cleared of sediment for $2 \mathrm{~d}$ in $50 \%$ offshore seawater at ambient temperature prior to histological examination. Conventional light microscopy was used to determine gonadal structure and appearance, sex ratios and gametogenic status. Oocyte sizes (with and without the chorionic membrane) were measured in a subset of 6 females from each site, using an eyepiece graticule at $\times 100$ magnification. The general condition of the clams (body weight as a function of shell length/ weight) was also recorded.

Experimental exposure to EDCs. Experiments were performed to establish whether or not exposure to known EDCs can cause changes in clam gonadal tissue similar to those observed in the field. In particular could EDCs be responsible for elevated levels of ovotestis and stimulation of oocyte development?

Laboratory exposure of adults to E2 and EE2 during peak gonad development: Because Scrobicularia plana is an infaunal deposit-feeding clam, sediment was the exposure medium chosen as a vector for EDCs. Fresh, oxidised surface mud was collected from the Avon Estuary on 4 June 2004 and sieved with $50 \%$ seawater to obtain the $<500 \mu \mathrm{m}$ fraction. Batches of $5 \mathrm{~kg}$ each were slurried with $50 \%$ seawater (collected off Plymouth), using a mechanical stirrer, and spiked with nominal sediment concentrations of $100 \mu \mathrm{g} \mathrm{kg}^{-1}$ wet wt (WW), 17ß-oestradiol (E2) or $100 \mathrm{\mu g} \mathrm{kg}^{-1}$ (WW) 170-ethinyloestradiol (EE2). These concentrations are somewhat higher than most published environmental values for sediment (e.g. up to $\sim 25 \mu \mathrm{g} \mathrm{kg}^{-1} \mathrm{E} 2$, EE2 on a dry weight basis; López de Alda \& Barceló 2001, Tashiro et al. 2003; for review see Langston et al. 2005) and are intended to represent a 'polluted' scenario. A comparable batch of sediment was spiked with $0.5 \mathrm{ml}$ ethanol, the carrier used for EDCs (ethanol control). The wet:dry wt ratio of the sediment was 2.06.

We transferred the $5 \mathrm{~kg}$ batches of spiked and unspiked sediments (mud control) to experimental glass tanks (12 l), and allowed them to settle for $24 \mathrm{~h}$, before rinsing twice with 61 clean $50 \%$ seawater (final volume).

Batches of 30 maturing Scrobicularia plana (Avon) (mean shell length $30.2 \pm 6.3 \mathrm{~mm}$, collected in early 
June at the same time as sediment) were acclimated in $50 \%$ seawater for $7 \mathrm{~d}$, and subsequently exposed to the different sediment treatments, for $6 \mathrm{wk}$. The salinity and temperature were maintained at $17.5 \%$ and $15^{\circ} \mathrm{C}$, respectively, and the light:dark cycle set at 12:12 h. Apart from the sediment on which these clams normally feed, no additional nutritional material was added to the tanks. Gonad condition, sex ratio and oocyte sizes were determined in these clams during the last week of July 2004, to correspond with the period of maximum development. A further 30 S. plana were collected from the Avon Estuary in July 2004, to provide an additional 'field control' sample for comparison.

Exposure of undifferentiated adults to E2, EE2, NP and OP: We examined possible effects of sedimentbound oestrogens and xenoestrogens on adult clams during an earlier 'window of sensitivity', starting in winter months before differentiation and follicle development was fully initiated. The aim was to establish reproductive effects of low- and high-level exposure to sediment-bound mixtures of E2, EE2, NP and OP throughout gonad development.

Scrobicularia plana and sediment were collected from the Avon Estuary on 28 and 31 January 2005. Sediments were prepared in duplicate as described in the previous section and spiked with a mixture of EDCs to give the following nominal 'low-dose' concentrations: $100 \mu \mathrm{g} \mathrm{kg}^{-1} \mathrm{E} 2(\mathrm{WW})+100 \mu \mathrm{g} \mathrm{kg}^{-1} \mathrm{EE} 2(\mathrm{WW})$ $+1000 \mu \mathrm{g} \mathrm{kg}^{-1} \mathrm{NP}(\mathrm{WW})+1000 \mu \mathrm{g} \mathrm{kg}^{-1} \mathrm{OP}$ (WW). These concentrations were increased by a factor of 10 in the 'high-dose' treatments (concentrations not expected in the environment but used to see if these EDCs represent a potential threat under worst-case conditions). Controls again comprised $S$. plana held in ethanol-spiked and unspiked sediment. The wet:dry wt ratio for sediment used in these experiments was 1.86 .

We placed 45 Scrobicularia plana (shell length $31.6 \pm$ $9.5 \mathrm{~mm}$ ) into each of the 4 (duplicate) treatments in the first week of February and maintained them at $10^{\circ} \mathrm{C}$ with aeration. Hours of daylight/darkness corresponded to those of sunrise/sunset in the field.

After 1 mo exposure, Scrobicularia plana were taken from one set of the duplicate tanks, then rinsed, dried and marked, before being transplanted back to the Avon Estuary for a further 4 mo. The other set of tanks and clams were maintained intact in the laboratory, and temperature and light regimes were adjusted to match those in the field. Between 7 and 13 July 2005, at the start of the spawning period, surviving clams from these 4 mo exposures (transplant and laboratory) were recovered and examined histologically.

Data (oocyte size, gender) were recorded on 'Microsoft Excel' spreadsheets and imported into 'Statistica'.
Fisher exact and chi-square tests were applied to the gender data to establish any differences in sex ratio within and between groups. Homogeneity of variances for the oocyte size data was determined by Levene's test. A $\log _{10}$ transformation was performed where the variances were not homogeneous. The data were then subjected to Tukey's HSD (honest significant difference) test for unequal $\mathrm{N}$ (Spjotvoll Stoline test) to reveal any significant differences between groups.

\section{RESULTS}

\section{Gonad status and intersex development in field populations}

In populations of Scrobicularia plana from the Southwest UK, gonad differentiation becomes evident during June, and by early July the majority of adults have well-developed gonadal cells, which, in the majority of individuals, are either sperm or oocytes (Fig. 2A,B). Gonadal development in Avon clams peaked in late July/early August. By October, with spawning over for the year, follicles in the gonads were empty and undifferentiated, preventing gender determination.

Superficial screening of the gonads indicated no significant departure from unity in the ratio male:female clams collected between June and September ( $p>0.05$, chi-square). However, more detailed histological examination of the population from the Avon Estuary revealed that a significant percentage of the male gonads contained oocytes (ovotestis), in addition to sperm cells (Fig. 2C). The incidence of this intersex condition increased during development, until peak spawning (in late July), and receded as the gonads regressed (Fig. 3 shows data for 2005). The maximum percentage of males affected by intersex in the Avon Estuary in late July was $48 \%$ (23\% of total population).

For Avon Scrobicularia plana collected on 7 July 2005, proportions of males with intersex (26 vs. $23 \%$ ) and male:female sex ratios (1.05 vs. 0.76 ) were comparable, irrespective of whether the sample size was 150 or 30. A standard sample size of 30 clams was therefore considered adequate for gender determination.

Our results reveal varying degrees of 'severity' of intersex in Scrobicularia plana, ranging from a single oocyte in a field of view (at $\times 100$ magnification) to clusters of oocytes, whole follicles packed with oocytes and, in extreme cases, gonads dominated by 'female' follicles. The present study of $S$. plana populations from the Southwest UK has also established that intersex is widespread and that the condition reflects feminisation of male clams. Thus, the proportion of females in the populations examined did not deviate from the expected $(\sim 50 \%)$, whilst males 
A

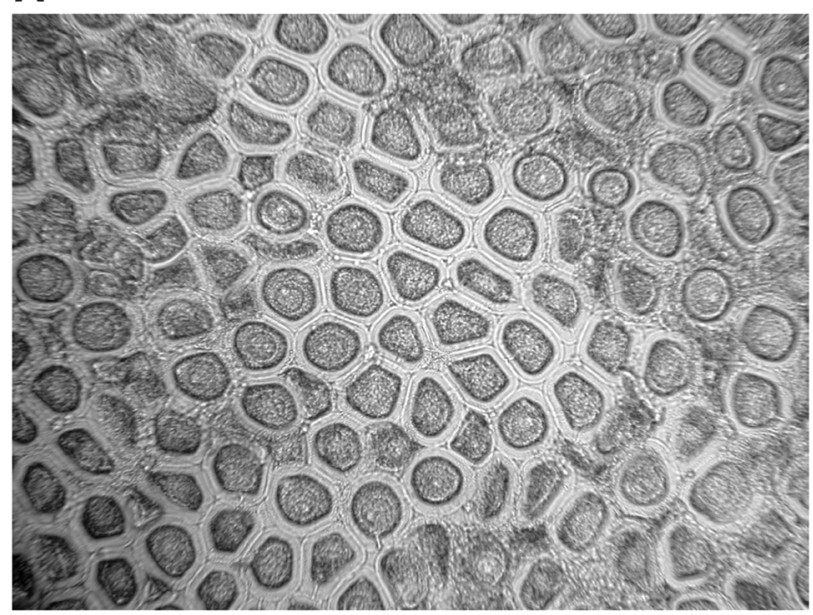

B

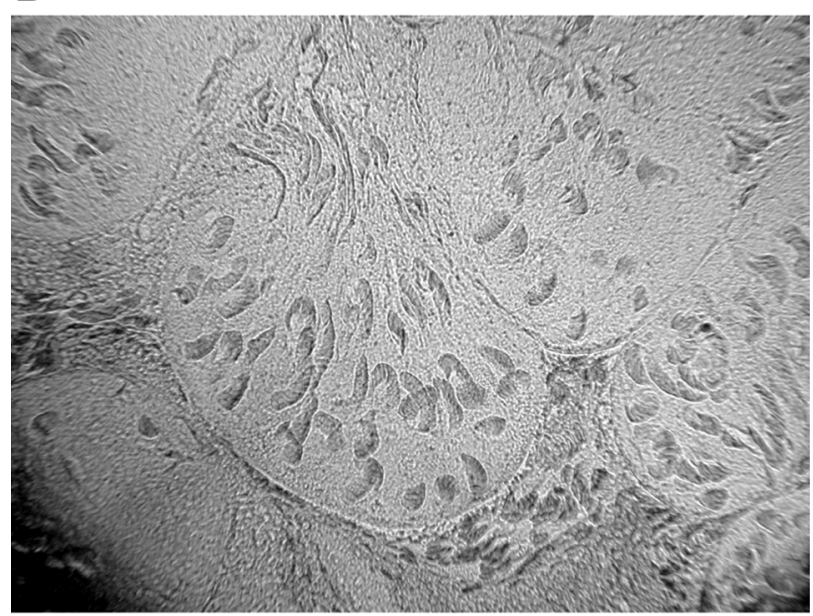

C

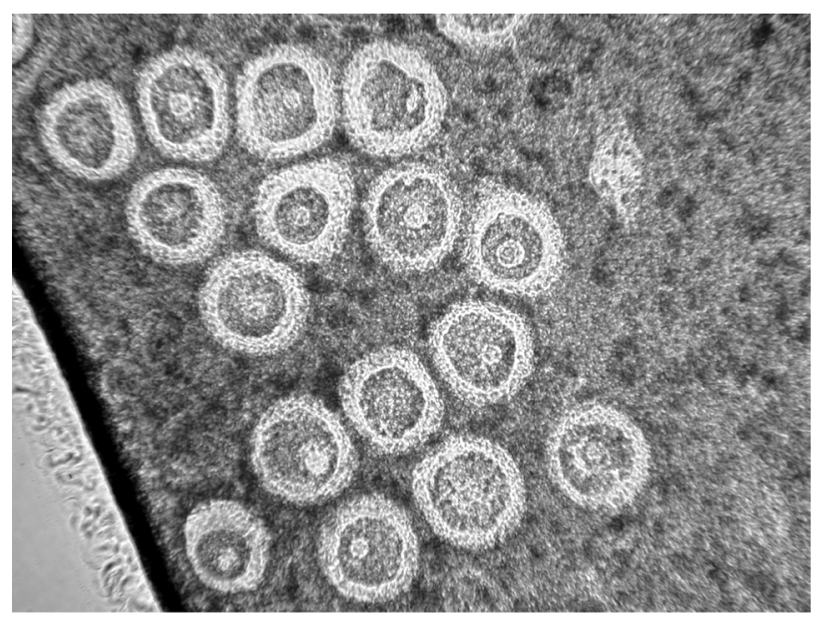

Fig. 2. Scrobicularia plana. Light micrographs $(\times 100)$ of $(A)$ female, (B) male and (C) intersex (presence of oocytes in male) gonads. Size of oocytes $=\sim 80$ to $100 \mu \mathrm{m}$

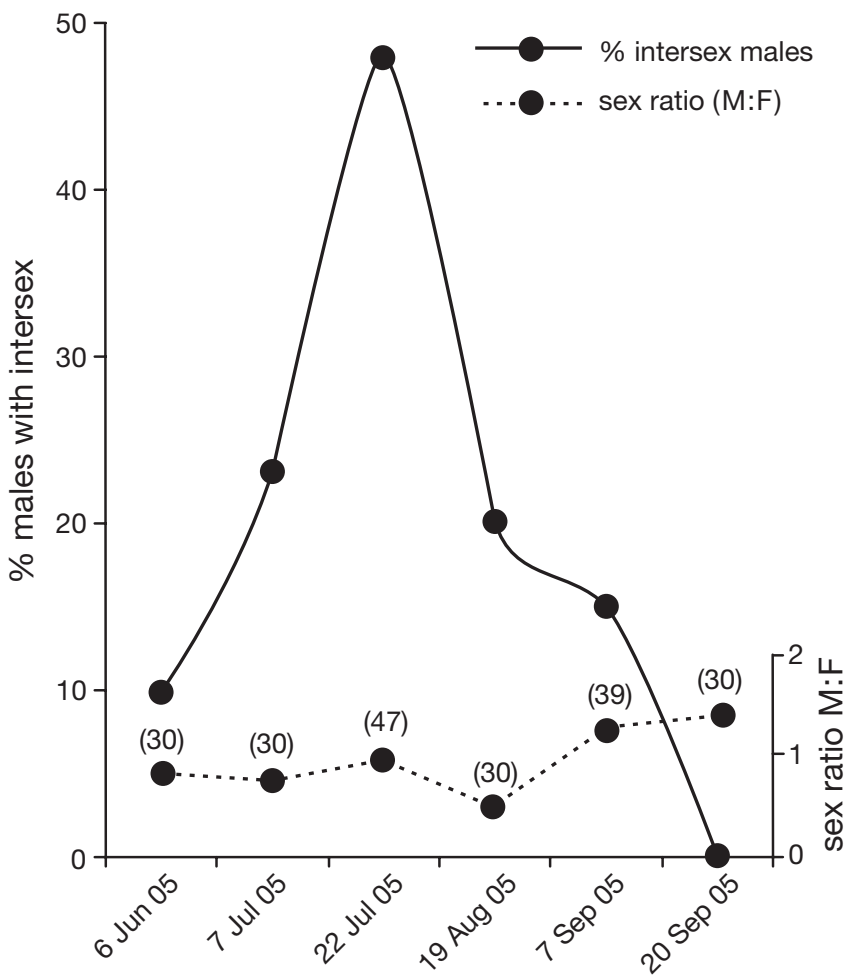

Fig. 3. Scrobicularia plana. Incidence of ovotestis and sex ratios during summer gonad development and spawning period (numbers of clams sampled in parentheses). Sex ratios do not differ from unity if intersex individuals are assumed to be 'affected' males (chi-square test, $\mathrm{p}>0.05$ )

exhibited varying degrees intersex/ovotestis (Figs. 3 \& 4): only by assuming that all intersex individuals are inherently 'males' is the sex ratio maintained at unity throughout.

Sites in Devon and Cornwall estuaries (see Fig. 4) where intersex was not evident in Scrobicularia plana in 2004 included the lower Plym and the Erme; again no significant departure from unity in the male:female ratio was observed. However, in 2005, screening of samples from the upper Plym (nearer to a sewagetreatment works [STW] outfall) and also the Erme (rural site) revealed a number of affected individuals (13 to $16 \%$ of the total population with intersex, equivalent to $30 \%$ of males: Fig. $4 \mathrm{~A}$ ). At the 6 sites examined in the Tamar and Lynher estuary complex, the incidence of intersex was 0 to $7 \%$ of the total population. Expressed as percentage of males exhibiting the condition, values ranged from $0 \%$ at Wilcove and Antony to $25 \%$ at St. Germans (mean 9\%). Sex ratios were biased towards females at 2 of the 6 sites surveyed in this system (Cargreen and St. Germans, p < 0.05, chisquare test); $21 \%$ of clams from Restronguet Creek (a metal-contaminated branch of the Fal Estuary) were intersex (Fig. 4A), equivalent to $44 \%$ males affected by the condition. 
In the estuaries feeding Southampton Water, male clams with ovotestis were present at 5 of the 7 sites examined (mean $5 \%$ of population with intersex, maximum $19 \%$ at the upper Itchen site; Fig. 4B: equivalent values for affected males were 12 and $40 \%$, respectively). Prevalence of intersex was generally highest in clams from the Itchen and Hamble sites and lowest in the Test Estuary. Intersex was not observed at Cracknore (Test) or St. Denys (Itchen).
Results of screening in the Loughor Estuary (Daltons Point), and sites in the outer Severn Estuary system (Barry Island, Penarth, Rhymney, South Wales) are shown in Fig. 4C and indicate a high incidence of intersex (14 to $33 \%$ of the population, with 37 to $100 \%$ of males affected), relative to the other locations surveyed. The overall trend suggests a possible increase in affected males in an upstream direction in the Severn Estuary. It should be noted, however, that only 6 clams were recovered at the Rhymney site (all females or intersex).

\section{Intersex development following experimental exposure to EDCs}

Following laboratory exposure of undifferentiated adults to sediments spiked with a mixture of E2, EE2, OP and NP (1 mo) and subsequent transplant to the field (4 mo) there was an indication that intersex condition had been induced by the lowdose treatment (nominal dose $100 \mu \mathrm{g} \mathrm{kg}^{-1}$ $\left.\mathrm{E} 2+\mathrm{EE} 2 ; 1000 \mu \mathrm{g} \mathrm{kg}^{-1} \mathrm{NP}+\mathrm{OP}\right) ; 44 \%$ of recovered males were found to have the ovotestis condition, compared to a much lower incidence in mud and ethanol controls (Table 1).

Recoveries of transplanted clams exposed to the higher exposure level (1 order of magnitude greater than the above concentrations) were too low for statistical analysis of intersex, suggesting that doses were toxic (though some oocytes were measured in survivors: see next subsection).

A poor recovery rate was observed in the continuous laboratory exposures run in parallel to these field transplants (survival $<15 \%$ at both low and high doses). At the higher dose in particular, anomalous clam behaviour could be seen from the start of the experiment, in that clam siphons were permanently extended for prolonged periods. Furthermore, survivors that were examined at the conclusion of these longterm laboratory experiments, including controls, appeared to have poorly developed gonads relative to specimens retrieved from the field (transplanted and native clams). Clearly, it is preferable to use field-based experiments and observations wherever possible, since long-term development appears be compromised in laboratory systems, even when attempts are made to mimic natural conditions.
Fig. 4. Scrobicularia plana. Contribution of male, female and intersex individuals to adult populations from estuarine sites in (A) Devon and Cornwall,

(B) Southampton Water and (C) Bristol Channel and Severn Estuary 
Table 1. Scrobicularia plana. Incidence of ovotestis following exposure to mixtures of oestrogens and xeno-oestrogens. Low dose: $100 \mu \mathrm{g} \mathrm{kg}^{-1} 17 \beta$-oestradiol (E2) and $17 \alpha$-ethinyloestradiol (EE2), $1000 \mu \mathrm{g} \mathrm{kg}^{-1}$ nonylphenol (NP) and octylphenol (OP). High dose: same components as for low dose, but concentrations 10-fold higher (see 'Materials and methods' for details). \% transplants recovered: clams recovered 4 mo after transplantation to field; Response: \% males with intersex. ${ }^{*} \mathrm{p}<0.05$, Fisher's exact test; nd: not determined (numbers too small)

\begin{tabular}{|lcc|}
\hline $\begin{array}{l}\text { Laboratory treatment } \\
(1 \mathrm{mo})\end{array}$ & $\begin{array}{c}\text { \% transplants } \\
\text { recovered }\end{array}$ & $\begin{array}{c}\text { Response } \\
(\%)\end{array}$ \\
\hline Control & 36 & 0 \\
$\quad$ Mud only & 47 & 7.7 \\
Ethanol-spiked mud & & \\
Exposed to E2 + EE2 + NP + OP & 51 & $44.4^{*}$ \\
$\quad$ Low dose & 6 & $\mathrm{nd}$ \\
High dose & 6 & \\
\hline
\end{tabular}

\section{Oocyte size in field and in laboratory-exposed clams}

Oocyte size in the Avon Scrobicularia plana population increased substantially from the beginning of June as development within follicles accelerated, and reached a maximum towards the end of July, the peak spawning period (Fig. 5A). Thereafter oocyte sizes appeared to regress gradually towards and during September. After this time few oocytes (or sperm) could be found in the gonads, marking the completion of spawning.

Oocyte measurements of Bristol Channel/Severn Estuary samples on 18 July 2005 (Fig. 5B) were broadly comparable in magnitude to those from the Avon sampled at roughly the same time (22 July 2005; Fig. 5A), though with some variation between individual sites. Thus, oocyte sizes in female gonads increased upstream in the Severn, towards Rhymney $(p<0.05$ Tukey's HSD test). This pattern was not dissimilar to the spatial trend seen for intersex levels in these clam populations. Oocyte sizes in intersex male clams from the Severn Estuary were consistently larger than those in females, as indicated in Fig. 5B, probably because they were not usually constrained in follicles (also observed in other populations). As with 'female' oocytes, there was a significant up-estuary increase in the size of 'male' oocytes in ovotestes (Rhymney and Penarth > Barry and Dalton's Point; $\mathrm{p}<0.05$ Tukey's HSD test for transformed data), in tandem with intersex frequency. The weight of evidence therefore suggests that, generally, feminising effects increased up-estuary in the Severn.

Experimental exposures of adult clams to E2 and EE2 during peak gonadal development were intended as a preliminary guide as to whether or not EDC may
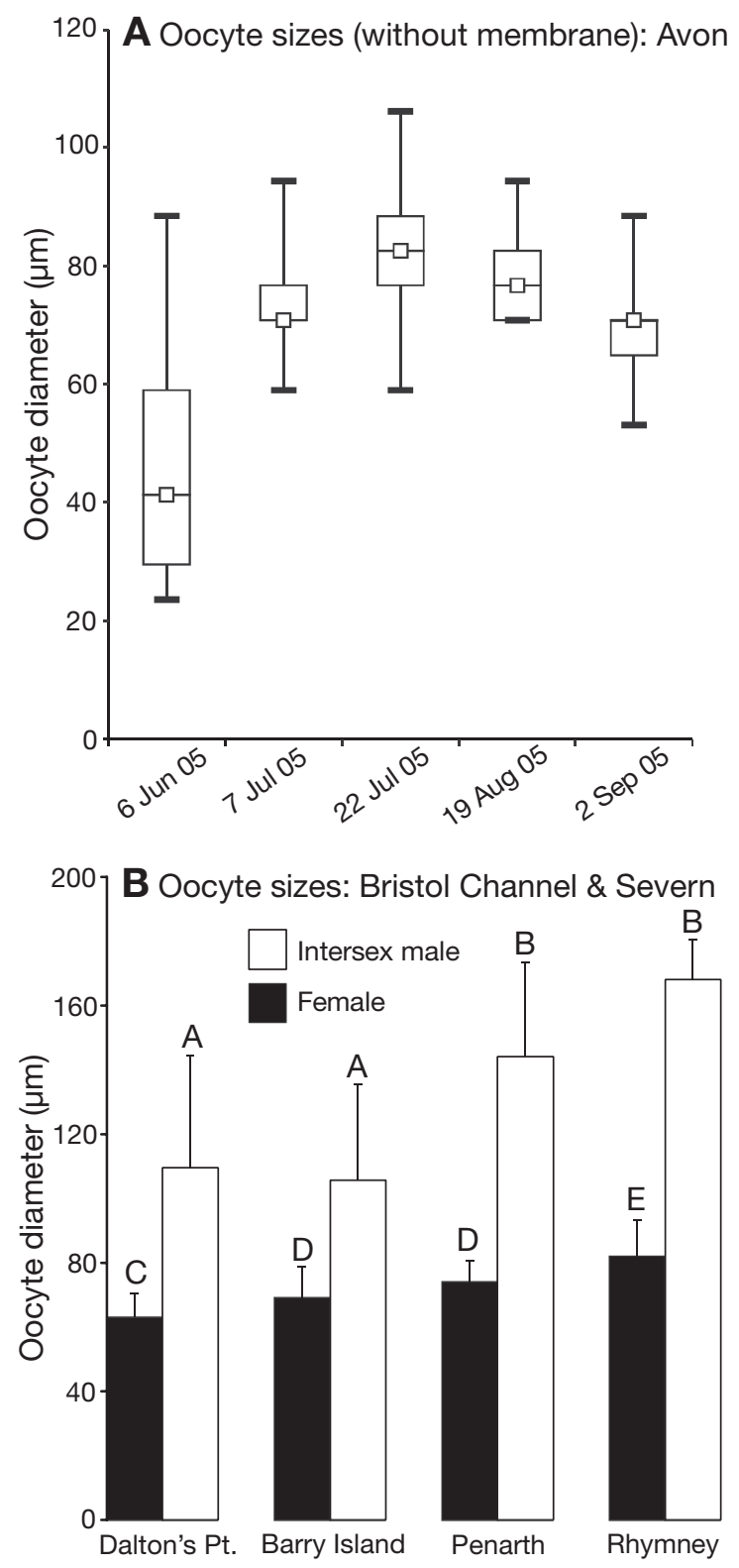

Fig. 5. Scrobicularia plana. Oocyte diameters (without membrane). (A) Median range, upper and lower quartiles) diameter for female clams from Avon Estuary; (B) mean $( \pm \mathrm{SD})$ diameter for female and male (intersex) clams from Bristol Channel and Severn Estuary. In (B), sites with same letters share homogenous grouping, otherwise sites are significantly different ( $p<0.05$; Tukey's HSD test)

be responsible for feminising effects. This was confirmed by results of the $6 \mathrm{wk}$ exposure to spiked sediment, which showed that oocytes were significantly larger in the E2- and EE2-exposed groups than controls (Table 2; p $<0.01$, Tukey's HSD test using transformed data for field controls).

Experimental exposure of undifferentiated clams to a mixture of EDCs for $1 \mathrm{mo}$, and subsequent transplant 
Table 2. Scrobicularia plana. Mean $( \pm \mathrm{SD})$ oocyte diameter $(\mu \mathrm{m})$, without membrane, following $6 \mathrm{wk}$ exposure of differentiated, developing clams to E2 and EE2 in sediment. Nominal dose $=100 \mu \mathrm{g} \mathrm{kg}^{-1} \mathrm{E} 2$ or EE2

\begin{tabular}{|lc|}
\hline & Oocyte diameter (mean $\pm \mathrm{SD})$ \\
\hline Control & \\
Laboratory & $69 \pm 9.2$ \\
Field & $52 \pm 26.5$ \\
Exposed & \\
E2 & $96 \pm 19$ \\
EE2 & $85 \pm 8.6$ \\
\hline
\end{tabular}

Table 3. Scrobicularia plana. Mean $( \pm \mathrm{SD})$ oocyte diameter $(\mu \mathrm{m})$ without membrane, following $4 \mathrm{wk}$ exposure of undifferentiated clams to mixtures of E2, EE2, NP and OP in sediment at low and high doses, followed by transplantation back to the field for 4 mo period. Nominal low dose $=100 \mu \mathrm{g} \mathrm{kg}^{-1} \mathrm{E} 2+$ EE2; $1000 \mu \mathrm{g} \mathrm{kg}^{-1} \mathrm{NP}+\mathrm{OP}$; nominal high dose $=1000 \mu \mathrm{g} \mathrm{kg}^{-1}$ $\mathrm{E} 2+\mathrm{EE} 2 ; 10000 \mu \mathrm{g} \mathrm{kg}^{-1} \mathrm{NP}+\mathrm{OP}$

\begin{tabular}{|lc|}
\hline & Oocyte diameter (mean $\pm \mathrm{SD})$ \\
\hline Control & \\
Mud & $69 \pm 10$ \\
Ethanol & $62 \pm 14$ \\
Exposed & \\
Low dose & $79 \pm 10$ \\
High dose & $78 \pm 8.6$ \\
\hline
\end{tabular}

to the field $(4 \mathrm{mo})$ resulted in small but significant increases in oocyte diameter in both the low- and highdose treatment compared to ethanol controls $(p<0.05$, Tukey's HSD test for transformed data; Table 3).

These results demonstrate that exposure to model oestrogens and xeno-estrogens during both early and late stages of gonad development may stimulate the growth of oocytes. It is therefore possible that EDCs could be responsible for some of the variation in oocyte size determined in samples from the Bristol Channel and Severn Estuary. However, it is important to stress that the concentrations used in sediment exposures were nominal and may not be environmentally realistic, other than at highly polluted sites. Further trials are needed to examine dose responses accurately and to evaluate a range of compounds.

\section{DISCUSSION}

Despite concern over ED in wildlife and humans, the possibility of effects in marine invertebrates has received scarce attention. The present study is one of the first to report oestrogenic-like symptoms in field populations of estuarine molluscs, in the form of increased oocyte development and ovotestis in the clam Scrobicularia plana. Experimental exposures to known EDCs (E2, EE2, OP and NP) indicate that these feminising effects are inducible in $S$. plana, though the mechanisms (and thresholds) of impact have yet to be determined and it is not yet certain that these observations are truly indicative of ED.

Whilst the endocrine systems of invertebrates tend to regulate the same processes as vertebrates-namely, development, growth, and reproduction-precise mechanisms may be unique to specific groups and, though all invertebrates extensively use neuropeptides to transduce neuroendocrine signals, steroid hormone usage appears to have undergone significant divergence. Clearly, a further drawback in interpretation of the present results (and one which we are trying to address) is the absence of chemical characterisation, leading to uncertainty over cause-effect relationships.

There are indications from published experimental studies with oestrogens and xeno-estrogens (E2, EE2, bisphenol-A, and 4-tert octylphenol) that the nature of the responses and their sensitivities may be generally similar in both vertebrates and invertebrates. For example, embryo production and egg-laying are stimulated in a comparable dose-dependent fashion in the fathead minnow Pimaphales promelas and the freshwater prosobranch mollusc Potamopyrgus antipodarum following exposure to concentrations of EE2 in the low $\left(<25 \mathrm{ng} \mathrm{l}^{-1}\right)$ dose range, but are inhibited at higher (>100 $\mathrm{ng} \mathrm{l}^{-1}$ ) doses, most notably in fish (Jobling et al. 2003). There may, however, be subtle differences in responses to different compounds: whilst freshwater fish are suggested to be more sensitive to disruption in reproductive output caused by steroid hormones, snails appear to be more responsive to very low concentrations of some xenoestrogens (e.g. bisphenol-A) and to oestrogenic effluent from wastewater treatment (Jobling et al. 2003).

The characteristics of ovotestis in Scrobicularia plana and induction following exposure to mixtures of oestrogens and xenoestrogens (E2, EE2, OP, NP) are similar to those observed in fish, for which ED, and the causes thereof, have been established more definitively (Tyler \& Routledge 1998, Jobling \& Tyler 2003). Furthermore, ovotestis is shown to be a widespread phenomenon in $S$. plana populations, with varying degrees of incidence and severity; this, too, seems to mirror the extensive and variable nature of ovotestis in freshwater and estuarine fish from UK catchments and implies that both may be symptomatic of ED caused by anthropogenic factors. To date we have observed ovotestis in S. plana from the Avon, Southampton Water, Erme, Plym, Bristol Channel and Severn, Fal, Tamar and Lynher Estuaries. In total, more than two-thirds of the sample populations examined displayed the phe- 
nomenon, with the prevalence at individual sites varying between 0 and $60 \%$ of males affected.

Severity of ovotestis in Scrobicularia plana populations ranged from a single oocyte in otherwise normal testicular tissue to large regions of mature ovarian tissue (in follicles) interspersed with abnormal testicular tissue. We are currently constructing a ranking system of the condition, adapted from a scoring index used to categorise different degrees of intersex in fish (Bateman et al. 2004). The scheme, based on histological examination completed to date, has identified 6 stages in clams (Chesman \& Langston 2006) and will be used as an additional parameter in the evaluation of intersex in future comparisons. Based on current evidence, the levels of severity and frequency in S. plana populations appear to be analogous to those in fish.

The Avon Estuary was selected originally as a potential control site to characterise the 'normal' sexuality of $S$. plana, because of the absence of major urbanisation and industry. The presence of ovotestis in some males from this estuary is therefore surprising (given that $S$. plana has hitherto been considered gonochoristic) and implies a degree of feminisation: oestrogenic influences would seem to be possible, even at apparently near-pristine rural sites. Establishing a true baseline for the species is an important priority for the future but may prove difficult since there are likely to be few, if any, estuaries that are completely free from human impact.

Intersex was not found at every site, and strict gonochorism could indeed be the true reference condition in Scrobicularia plana. Certainly, the intersex condition does not reflect functional hermaphroditism in these clams. However, when intersex occurrence is averaged across sites within each estuary, it is apparent that none of the estuaries examined so far have completely gonochoristic S. plana populations (Fig. 6A). Thus, within the Tamar/Lynher complex (lowest average intersex levels of the estuaries examined) the incidence of intersex ranged from 0 to $25 \%$ at individual sites (Fig. 6B) with a mean of $9 \%$ (incidence expressed as percentage of males with the condition). Faced with this uncertainty over baselines, and until there is stronger evidence of causality, caution needs to be applied when interpreting such data in terms of possible ED. Nevertheless, even if it is assumed that the $9 \%$ mean value for the Tamar/Lynher Estuaries represents the 'normal' condition rather than zero (i.e. a small percentage intersex is to be expected), populations from the Avon, Fal and Severn Estuaries/Bristol Channel still have significantly higher intersex levels (Fisher exact test, p < 0.005), which may be due to anthropogenic influences (Fig. 6A). Interestingly, the level of intersex induced in $S$. plana by experimental exposure to a mixture of EDCs (E2, EE2, OP and NP) (included in Fig. 6A for comparison) is similar to that in clams from the Severn Estuary/Bristol Channel.

The sites sampled in the Severn Estuary/Bristol Channel are industrialised and urbanised and subjected to STW and landfill runoff; the Fal (Restronguet Creek) has been subjected to exceptional levels of metal contamination and other inputs, including
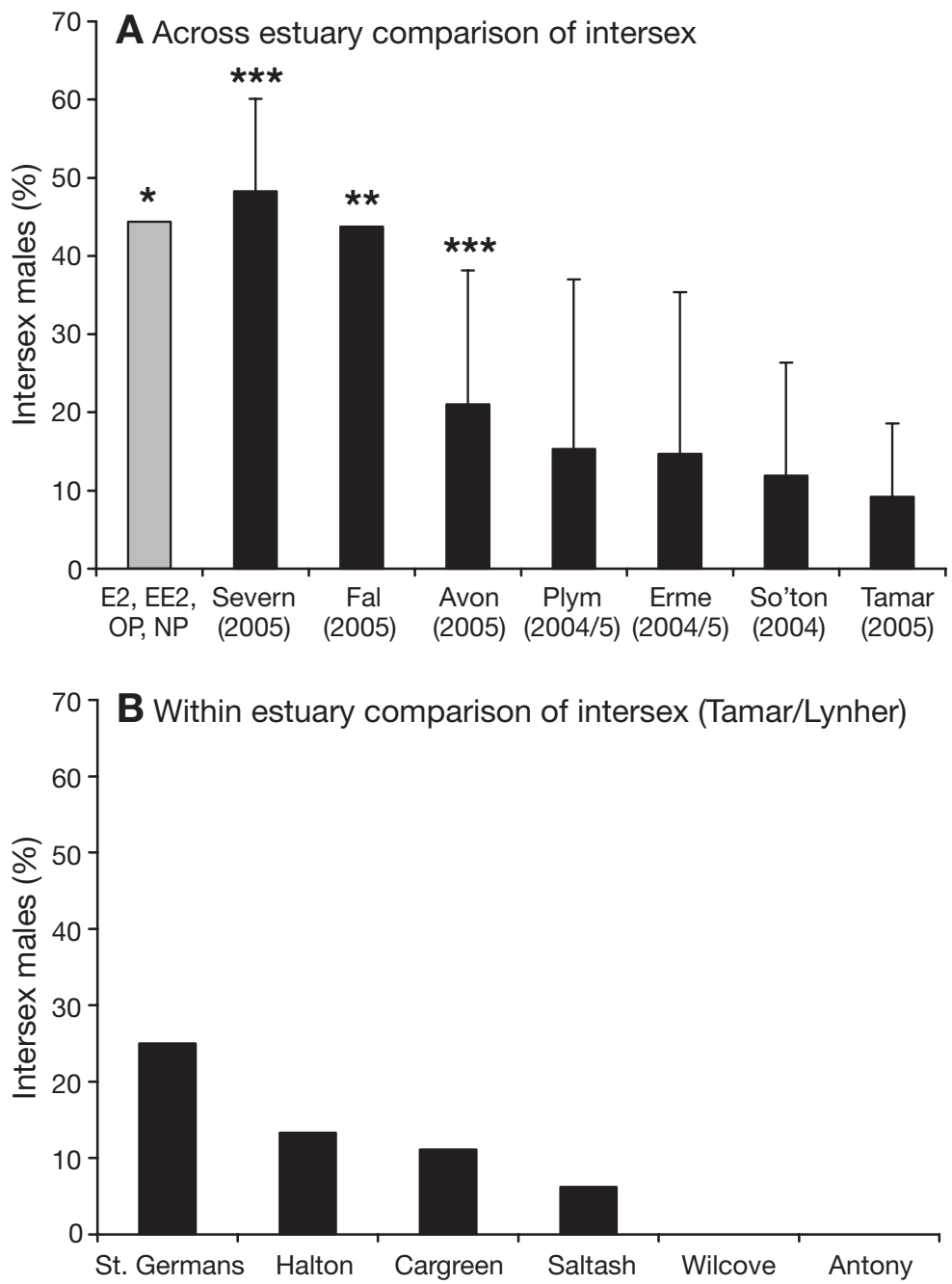

Fig. 6. Scrobicularia plana. (A) Mean (+SD) incidence of intersex in males from estuaries in Southwest UK, and in clams exposed experimentally to mixture of EDCs (level of significance of difference from Tamar 'reference' condition [Fisher's exact test] ${ }^{*} \mathrm{p}<0.05,{ }^{* *} \mathrm{p}<0.005,{ }^{* * *} \mathrm{p}<0.001$. (B) Range of intersex in clam populations from sites within Tamar/Lynher Estuary complex 
wastewater treatment. The raised incidence of intersex in Scrobicularia plana from the Avon is unlikely to be due to industrialisation since the catchment area is predominantly rural; however, outfalls from small STW and agricultural inputs from livestock are possible sources of oestrogenic compounds. Nearby commercial oyster beds in the Avon have been closed periodically because of high bacterial (Escherichia coli) counts, and though again there is ongoing debate as to the importance of wastewater and agricultural sources, the implication is that even 'undeveloped' estuaries can be affected by a relatively moderate level of anthropogenic activity.

Evidence from both the field (Bristol Channel and Severn Estuary) and experimental exposures indicates that (xeno)estrogens could be a contributory factor to the development and growth of oocytes in female and intersex male Scrobicularia plana, in a pattern which appears to parallel the prevalence of the ovotestis condition. Effects of EDC on germ cell development have been observed in other studies with molluscs, with varying consequences. Altered oocyte maturation (due to oocyte degradation) and delayed sperm release have been linked with DDT exposure in the freshwater mussel Dreissena polymorpha in contaminated sections of Lake Maggiore, Italy, and may be symptomatic of neuroendocrine interference; the resultant asynchrony between sexes could compromise reproductive success (Binelli et al. 2001, 2004). In contrast, injections of E2 (and other sex steroids, testosterone, and progesterone) stimulate both oogenesis and spermatogenesis in scallops and lead to increased gonad weight and, as in our study, larger oocyte diameter (Varaksina \& Varaksin 1991, Varaksina et al. 1992, Wang \& Croll 2004). Most significantly, injections of oestradiol at early stages of the seasonal sex maturation of the oyster Crassostrea gigas have been shown to induce sexual reversal from male to female (Mori et al. 1969), illustrating the potential effect of sex steroids on bivalve sexuality.

We have found no outstanding evidence, from sex ratio data, of complete sex reversal in Scrobicularia plana. Published records on the reproductive biology of $S$. plana, including all of those based on UK populations (Hughes 1971, Frankiel \& Moueza 1979, Ruiz 1993), describe the species as gonochoristic. Extensive histological examination of several hundred individuals from the Bidasoa Estuary (North Spain) and from the Guadalquivir river (Cadiz, SW Spain) has also confirmed the presence of separate sexes and a male: female sex ratio of 1:1, with no apparent 'hermaphroditism' (Sola 1997, Rodriguez-Rua et al. 2003). We are aware of only 1 study, from Portugal, which alludes to the presence of a small percentage (mean $2.8 \%$ ) of 'hermaphrodites' in a population of $S$. plana. This pop- ulation was sampled over a 1 yr period near to an oyster hatchery in the highly urbanised and industrialised Tagus Estuary, some 50 yr ago (Paes-da-Franca 1956). Interestingly, the peak incidence in 'hermaphrodites' $(4 \%)$ coincided with the period of highest sexual activity, as indicated in our present results for Avon clams. Presumably the Tagus clam population reflected a similar phenomenon to the intersex condition described here and did not represent functional hermaphroditism. It is perhaps surprising that intersex has not been reported more widely if the incidence of intersex/ ovotestis is as widespread as it appears to be in contemporary populations in the Southwest UK. However, as we have demonstrated, the location and timing of sampling (and method of sample preparation and screening) may influence observations. Even when these variables are controlled, there may be considerable variation in the incidence of intersex within an individual estuary, depending on site (e.g. 0 to $25 \%$ in the Tamar/Lynher complex).

In intersex freshwater fish such as roach, altered germ cell development (ovotestis) probably occurs as a consequence of long-term exposure to ED compounds, whilst changes in gonadal duct development are thought to occur following effluent exposure in early life (Jobling \& Tyler 2003). The major known causative agents are steroid oestrogens and alkyphenolic chemicals, though because of the complex nature of effluents, other chemicals may well be active in producing effects. Accompanying symptoms in fish include altered sex steroid hormone profiles, altered spawning time, reduced sperm production and motility, lower fertilisation success and, ultimately, compromised reproductive capacity (Jobling et al. 2002a,b). The implications of intersex for the fecundity of clams is unknown; however, the incidence of affected male Scrobicularia plana (up to $60 \%$ ) may sometimes be in excess of that observed in fish populations whose success appears to be compromised. It perhaps seems counterintuitive to anticipate population-level consequences in a broadcast spawner with planktotrophic larvae such as $S$. plana, unless some barrier to distribution was in operation. Nevertheless, although $S$. plana is theoretically capable of substantial lateral migration, this may occur only rarely in nature (Casagranda \& Boudouresque 2005). Faced with the prospect of elevated concentrations of EDCs and ensuing challenges to sexuality, failure to sustain clam populations, due to restriction in gamete/larval viability by EDCs, cannot be ruled out at some sites. The possibility of population responses in clams therefore merits further investigation.

Certainly, there is strong evidence that the androgenic antifouling compound TBT has affected populations of Scrobicularia plana and other bivalves through 
reductions in recruitment, albeit at a local level (Langston et al. 1990. Ruiz et al. 1994a,b). A wider decline and disappearance of $S$. plana populations from areas in the in the Danish and German Wadden Sea and the western half of the Dutch Wadden Sea, from undetermined causes, has also been reported (Essink et al. 1991). High mortality following spawning and settlement is not unusual, particularly if conditions are unfavourable (Casagranda \& Boudouresque 2005). It is not unconceivable, therefore, that $S$. plana populations may be vulnerable to the added pressure of ED, particularly close to sources of contamination. Bioaccumulation of ED compounds from sediment may exacerbate the risk to these and other deposit-feeders.

At present, the causes and consequences of the ovotestis condition in populations of Scrobicularia plana are speculative, but we have demonstrated that deviation from the perceived gonochoristic sexuality of $S$. plana is occurring widely in the Southwest UK and is inducible by known endocrine disruptors. The next priority is to look for wider evidence of reproductive impact in the field, to define true baselines more adequately, to investigate the links between sexuality of these bivalves and anthropogenic causes, and to examine the consequences for populations. Species such as S. plana and comparable 'gonochoristic' molluscs clearly offer potential for widespread screening and investigation of ED, helping to characterise the risks to marine life from environmental oestrogens. This, in turn, may help to guide the direction of future remediatory policy.

Acknowledgements. Thanks to R. Pipe at the MBA for advice on histology and for critical evaluation of the manuscript. Support from the Department for the Environment, Food and Rural Affairs, under the EDAQ programme (project CTG 0301), is gratefully acknowledged, particularly the helpful suggestions of M. Roberts and D. Sheehan. An NERC award NE/ C508726/1 also facilitated sampling throughout the SW region.

\section{LITERATURE CITED}

Allen Y, Scott A, Matthiessen P, Haworth S, Thain J, Feist S (1999) Survey of estrogenic activity in United Kingdom estuarine and coastal waters and its effects on gonadal development of the flounder Platichthys flesus. Environ Toxicol Chem 18:1791-1800

Bateman KS, Stentiford GD, Feist SW (2004) A ranking system for the evaluation of intersex condition in European flounder (Platichthys flesus). Environ Toxicol Chem 23: 2831-2836

Binelli A, Bacchetta R, Vailati G, Galassi S, Provini A (2001) DDT contamination in Lake Maggiore (N Italy) and effects on zebra mussel spawning. Chemosphere 45:409-415

Binelli A, Bacchetta R, Mantecca P, Ricciardi F, Provini A, Vailati G (2004) DDT in zebra mussels from Lake Maggiore ( $\mathrm{N}$. Italy): level of contamination and endocrine disruptions. Aquat Toxicol 69:175-188
Bryan GW, Langston WJ (1992) Bioavailability, accumulation and effects of heavy metals in sediments with special reference to United Kingdom estuaries: a review. Environ Pollut 76:89-131

Bryan GW, Gibbs PE, Hummerstone LG, Burt GR (1986) The decline of the gastropod Nucella lapillus around southwest England: evidence for the effect of tributyltin from antifouling paints. J Mar Biol Assoc UK 66:611-640

Casagranda C, Boudouresque CF (2005) Abundance, population structure and production of Scrobicularia plana and Abra tenuis (Bivalvia: Scrobicularidae) in a Mediterranean brackish lagoon, Lake Ichkeul, Tunisia. Int Rev Hydrobiol 90:376-391

Chesman BS, Langston WJ (2006) Intersex in the clam Scrobicularia plana: a sign of endocrine disruption in estuaries? Biol Lett 2:420-422

Defur PL, Crane M, Ingersoll C, Tattersfield L (1999) Endocrine disruption in invertebrates: endocrinology, testing and Assessment. Tech Publ, SETAC Press Pensacola, FL

Delgado M, Camacho AP (2002) Hermaphroditism in Ruditapes decussatus (L.) (Bivalvia) from the Galician coast (Spain). Sci Mar 66:183-185

Essink K, Beukema JJ, Coosen J, Craeymeersch JA, Ducrotoy JP, Michaelis H, Robineau B (1991) Population dynamics of the bivalve mollusc Scrobicularia plana da Costa: comparisons in time and space. In: Elliott M, Ducrotoy JP (eds) Estuaries and coasts: spatial and temporal intercomparisons. Olsen \& Olsen, Fredensborg, p 167-172

Frankiel L, Moueza M (1979) Larval development of two Tellinacea Scrobicularia plana (Semelidae) and Donax vittatus (Donacidae). Mar Biol 55:187-195

Horiguchi T, Takiguchi N, Cho HS, Kojima M and 5 others (2000) Ovo-testis and disturbed reproductive cycle in the giant abalone, Haliotis madaka: possible linkage with organotin contamination in a site of population decline. Mar Environ Res 50:223-229

Hughes RN (1971) Reproduction of Scrobicularia plana Da Costa (Pelecypoda: Semelidae) in North Wales. Veliger 14:77-81

Jobling S, Tyler CR (2003) Endocrine disruption in wild freshwater fish. Pure Appl Chem 75:2219-2234

Jobling S, Beresford N, Nolan M, Rodgers-Gray T, Brighty GC, Sumpter JP, Tyler CR (2002a) Altered sexual maturation and gamete production in wild roach (Rutilus rutilus) living in rivers that receive treated sewage effluents. Biol Reprod 66:272-281

Jobling $\mathrm{S}$, Coey $\mathrm{S}$, Whitmore JG, Kime DE and 7 others (2002b) Wild intersex roach (Rutilus rutilus) have reduced fertility. Biol Reprod 67:515-524

Jobling S, Casey D, Rodgers-Gray T, Oehlmann J and 5 others (2003) Comparative responses of molluscs and fish to environmental estrogens and an estrogenic effluent. Aquat Toxicol 65:205-220

Langston WJ, Burt GR (1991) Bioavailability and effects of sediment-bound TBT in deposit-feeding clams, Scrobicularia plana. Mar Environ Res 32:61-77

Langston WJ, Bryan GW, Burt GR, Gibbs PE (1990) Assessing the impact of tin and TBT in estuaries and coastal regions. Funct Ecol 4:433-443

Langston WJ, Burt GR, Chesman BS, Vane CH (2005) Partitioning, bioavailability and effects of oestrogens and xenooestrogens in the aquatic environment. J Mar Biol Assoc UK 85:1-31

Lintelmann J, Katayama A, Kurihara N, Shore L, Wenzel A (2003) Endocrine disruptors in the environment. Pure Appl Chem 75:631-681

López de Alda MJ, Barceló D (2001) Use of solid-phase extraction in various of its modalities for sample preparation 
in the determination of estrogens and progestogens in sediment and water. J Chromatogr 938:145-153

Mackie GL (1984) Bivalves. In: Tompa AS, Verdonk NH, van den Biggelaar JAM (eds) The Mollusca, Vol 7. Reproduction. Academic Press, New York, p 351-418

Mori K, Muramatsu T, Nakamura Y (1969) Effect of steroid: III. Sex reversal from male to female in Crassostrea gigas by estradiol-17h. Bull Jpn Soc Sci Fish 35: 1072-1076

Nolan M, Jobling S, Brighty G, Sumpter JP, Tyler CR (2001) A histological description of intersexuality in the roach. J Fish Biol 58:160-176

Oehlmann J, Schulte-Oehlmann U, Tillmann M, Markert B (2000) Effects of endocrine disruptors on prosobranch snails (Mollusca: Gastropoda) in the laboratory. Part I: Bisphenol A and octylphenol as xeno-estrogens. Ecotoxicology 9:383-397

Paes-da-Franca ML (1956) Variacao sazonal das gonadas em Scrobicularia plana da Costa. Arq Mus Bocage Nov Ser 27:107-124

Peck M, Gibson RW, Kortenkamp A, Hill EM (2004) Sediments are major sinks of steroidal estrogens in two United Kingdom rivers. Environ Toxicol Chem 23:945-952

Rodríguez-Rúa A, Prado MA, Romero Z, Bruzón M (2003) The gametogenic cycle of Scrobicularia plana (da Costa, 1778) (Mollusc: Bivalve) in Guadalquivir estuary (Cádiz, SW Spain). Aquaculture 217:157-166

Ruiz JM (1993) Metallic pollution in estuaries, with special reference to the effects of tributyltin (TBT) and copper on the early life stages of Scrobicularia plana (Mollusca: Bivalvia). PhD dissertation, University of Plymouth

Ruiz JM, Bryan GW, Gibbs PE (1994a) Chronic toxicity of water tributyltin (TBT) and copper to spat of the bivalve

Editorial responsibility: Otto Kinne (Editor-in-Chief), Oldendorf/Luhe, Germany
Scrobicularia plana: ecological implications. Mar Ecol Prog Ser 113:105-117

Ruiz JM, Bryan GW, Gibbs PE (1994b) Bioassaying the toxicity of tributyltin-(TBT)-polluted sediment to spat of the bivalve Scrobicularia plana. Mar Ecol Prog Ser 113: $119-130$

Sola JC (1997) Reproduction, population dynamics, growth and production of Scrobicularia plana da Costa (pelecypoda) in the Bidasoa estuary, Spain. Aquat Ecol 30: 283-296

Stentiford GD, Feist SW (2005) First reported cases of intersex (ovotestis) in the flatfish species dab Limanda limanda: Dogger Bank, North Sea. Mar Ecol Prog Ser 301:307-310

Tashiro Y, Takemura A, Fujii H, Takahira K, Nakanishi Y (2003) Livestock wastes as a source of estrogens and their effects on wildlife of Manko tidal flat, Okinawa. Mar Pollut Bull 47:143-147

Tyler CR, Routledge EJ (1998) Oestrogenic effects in fish in English rivers with evidence of their causation. Pure Appl Chem 70:1795-1804

Tyler CR, Jobling S, Sumpter JP (1998) Endocrine disruption in wildlife: a critical review of the evidence. Critical Rev Toxicol 28:319-361

Varaksina GS, Varaksin AA (1991) Effect of estradiol, progesterone, and testosterone on oogenesis of Yezo scallop. Russ J Mar Biol 17:162-167

Varaksina GS, Varaksin AA, Maslennikova LA (1992) The role of gonadal steroid hormones in the spermatogenesis of the scallop Mizuhopecten yessoensis. Russ J Mar Biol 18:77-83

Wang C, Croll RP (2004) Effects of sex steroids on gonadal development and gender determination in the sea scallop, Placopecten magellanicus. Aquaculture 238:483-498

Submitted: April 10, 2006; Accepted: July 6, 2006

Proofs received from author(s): March 5, 2007 